\title{
Effect of Phosphorus and Gypsum on Growth, Yield and Economics of Groundnut (Arachis hypogea L.)
}

\author{
D. R. M. S. Vidya Sagar*, Joy Dawson and Ramasahayam Uday Kumar Reddy
}

Department of Agronomy, Sam Higginbottom University of Agriculture, Technology and Sciences, Prayagraj, Uttar Pradesh, India

*Corresponding author

\section{A B S T R A C T}

\begin{tabular}{|l|}
\hline Ke y w or d s \\
Groundnut, kharif, \\
Gypsum, \\
Phosphorus, \\
Growth, Yield, \\
Economics
\end{tabular}

\section{Introduction}

Groundnut (Arachis hypogea L.) is an important oil seed crop and a grain legume. India is the second largest producer of Groundnut after China. It contributed to sustainable agriculture being a legume and is cultivated in both kharif and Zaid by farmers. According to (Satish et al., 2011), groundnut is primarily used for extraction of oil, with an analysis of about $46.70 \%$. It is also consumed directly because of its high food value, which is again due to its higher content of protein $(22.0 \%)$, carbohydrate $(10.0 \%)$ and minerals (3.0\%).
Among different agronomic practices, nutrient management is one which accelerates growth and productivity of the crop. Phosphorus is essential for the formation of chlorophyll and protoplasm, cell division and development of meristematic tissues, also helps in the seed development and maturity of plant. This nutrient is required for synthesis of oil, protein, acid and is also involved in formation of glucosinolates which on hydrolysis increases the oil content. Its deficiency causes severe restriction in the growth of plant tops and root (Mirvat et al., 2006). 
Gypsum is widely used as a source of Calcium and Sulphur for groundnut worldwide. The dissolution of gypsum is fairly rapid and therefore readily adds $\mathrm{Ca}$ and $\mathrm{S}$ to the podding zone. Survey data from the small holder farming sector has shown that the majority of the farmers apply gypsum to get good yield of groundnut (Sreelatha et al., 2004). Application of gypsum split doses facilitate the calcium and Sulphur requirement for better shell development and oil content in critical pod development period of plant growth.

\section{Materials and Methods}

A field experiment was conducted during kharif 2019 at Central Crop Research Farm, Department of Agronomy, SHUATS, Prayagraj, (U.P). The soil of experimental plot was sandy loam in texture, nearly neutral in soil reaction ( $\mathrm{pH} 7.3)$, low inorganic carbon $(0.57 \%)$, medium in available $\mathrm{N}(230 \mathrm{~kg} / \mathrm{ha})$, high in available $\mathrm{P}(32.10 \mathrm{~kg} / \mathrm{ha})$ and low in available K (346 kg /ha). The treatments consists of 3 levels of Phosphorus viz. $\mathrm{P}_{1}$ (40 $\left.\mathrm{kg} \mathrm{P}_{2} \mathrm{O}_{5} / \mathrm{ha}\right), \mathrm{P}_{2}\left(50 \mathrm{~kg} \mathrm{P}_{2} \mathrm{O}_{5} / \mathrm{ha}\right), \mathrm{P}_{3}(60 \mathrm{~kg}$ $\left.\mathrm{P}_{2} \mathrm{O}_{5} / \mathrm{ha}\right)$ and 3 levels of Gypsum viz. $\mathrm{G}_{1}(200$ $\left.\mathrm{kg} \quad \mathrm{CaSO}_{4} \cdot 2 \mathrm{H}_{2} \mathrm{O} / \mathrm{ha}\right), \quad \mathrm{G}_{2} \quad(300 \quad \mathrm{~kg}$ $\left.\mathrm{CaSO}_{4} \cdot 2 \mathrm{H}_{2} \mathrm{O} / \mathrm{ha}\right)$ and $\mathrm{G}_{3} \quad(400 \quad \mathrm{~kg}$ $\mathrm{CaSO}_{4} \cdot 2 \mathrm{H}_{2} \mathrm{O} / \mathrm{ha}$ ) as both basal and side dressing. There were 9 treatments each replicated thrice. The experiment was laid out in Randomized Block Design. It was sown on $20^{\text {th }}$ July 2019 at a spacing of $30 \mathrm{~cm} \times 10 \mathrm{~cm}$. Nitrogen (20 Kg/ha) and Potassium (40 $\mathrm{Kg} / \mathrm{ha}$ ) are applied at basal and Nitrogen was applied as splits (Basal and split at 30 DAS).

\section{Results and Discussion}

Dry weight was significantly affected by phosphorus and gypsum at different levels. Groundnut crop fertilized with the application of phosphorus $60 \mathrm{~kg} / \mathrm{ha}$ along with gypsum $400 \mathrm{~kg} / \mathrm{ha}(75 \%$ basal $+25 \%$ side dressing at
35 DAS) was significantly resulted in plant highest Dry weight (56.3g) at 100 DAS (Table 1).

The increases in dry weight due to phosphorus application may be due to the fact that phosphorus is known to help in the development of more extensive root system Sharma and Yaday (1997) and thus enables plants absorb more water and nutrients from depth of the soil. This in turn could enhance the plant's ability to produce more assimilates which were reflected in the enhanced biomass production.

Yield attributes and yield were also significantly affected by phosphorus and gypsum at different levels. Groundnut crop fertilized with the application of phosphorus $60 \mathrm{~kg} / \mathrm{ha}$ along with gypsum $300 \mathrm{~kg} / \mathrm{ha}(75 \%$ basal $+25 \%$ side dressing at 35 DAS) was significantly resulted in Number of Pods/Plant (32) and Kernel yield (2484.3 kg/ha) (Table 1)

The increased number of Pods/Plant might be due to effect of phosphatic fertilizer that increased nutrient availability, resulting in better nutrient absorption and crop growth. The results are in conformity with the findings of Bandopadhyay and Samui (1999), Choudary et al., (2015), Hasan and Ismail (2016) and Amruth et al., (2017). Application of gypsum increased the haulm yield and kernel yield of groundnut crop. Further, application of gypsum each at basal and flowering recorded the highest kernel yield. The increase in haulm and kernel yield due to application of gypsum was attributed to concomitant influence of Sulphur released from the gypsum on availability of other nutrients from the soil and their extraction by the plant seems to have provided congenial nutritional environment for the plants. Further, calcium plays an important role in the reproductive development of the 
groundnut crop, thereby increased the pod yield. These results are in agreement with the findings of Rao and Shaktawat (2001) and Sreelatha et al., (2004).

Table.1 Effect of phosphorus and gypsum on growth, yield and economics of groundnut

\begin{tabular}{|c|c|c|c|c|c|}
\hline Treatments & $\begin{array}{c}\text { Dry weight } \\
\text { (g/plant) } \\
\text { at } 100 \mathrm{DAS}\end{array}$ & $\begin{array}{l}\text { Pods/ } \\
\text { Plant } \\
\text { (No.) }\end{array}$ & $\begin{array}{c}\text { Kernel } \\
\text { Yield } \\
\text { (kg/ha) }\end{array}$ & $\begin{array}{c}\text { Net } \\
\text { Returns } \\
\text { (Rs./ha) }\end{array}$ & $\begin{array}{c}\text { Benefit } \\
\text { Cost } \\
\text { Ratio }\end{array}$ \\
\hline $1.40 \mathrm{~kg}$ P/ha $+200 \mathrm{~kg}$ G/ha (100\% basal) & 44.3 & 25.6 & 1658.27 & 100969 & 3.01 \\
\hline $2.40 \mathrm{~kg} P / \mathrm{ha}+300 \mathrm{~kg} \mathrm{G} / \mathrm{ha}(100 \%$ basal $)$ & 44.5 & 25.2 & 1735.27 & 106357 & 3.04 \\
\hline $3.40 \mathrm{~kg} P / \mathrm{ha}+400 \mathrm{~kg}$ G/ha $(100 \%$ basal $)$ & 45.1 & 26.1 & 1711.60 & 102568 & 2.91 \\
\hline $\begin{array}{l}4.50 \mathrm{~kg} \mathrm{P} / \mathrm{ha}+200 \mathrm{~kg} \mathrm{G} / \mathrm{ha}(50 \% \text { basal }+ \\
50 \% \text { side dressing at } 35 \text { DAS })\end{array}$ & 49.3 & 27.6 & 2218.00 & 149694 & 3.85 \\
\hline $\begin{array}{l}5.50 \mathrm{~kg} \mathrm{P} / \mathrm{ha}+300 \mathrm{~kg} \mathrm{G} / \mathrm{ha}(50 \% \text { basal }+ \\
50 \% \text { side dressing at } 35 \text { DAS })\end{array}$ & 51.6 & 27.3 & 2376.33 & 162393 & 3.99 \\
\hline $\begin{array}{l}6.50 \mathrm{~kg} \mathrm{P} / \mathrm{ha}+400 \mathrm{~kg} \mathrm{G} / \mathrm{ha}(50 \% \text { basal }+ \\
50 \% \text { side dressing at } 35 \text { DAS })\end{array}$ & 54.3 & 27.4 & 2203.67 & 145074 & 3.59 \\
\hline $\begin{array}{l}\text { 7. } 60 \mathrm{~kg} \mathrm{P} / \mathrm{ha}+200 \mathrm{~kg} \mathrm{G} / \mathrm{ha}(75 \% \text { basal }+ \\
25 \% \text { side dressing at } 35 \mathrm{DAS})\end{array}$ & 55.6 & 29 & 2254.00 & 152937 & 3.9 \\
\hline $\begin{array}{l}8.60 \mathrm{~kg} \mathrm{P} / \mathrm{ha}+300 \mathrm{~kg} \mathrm{G} / \mathrm{ha}(75 \% \text { basal }+ \\
25 \% \text { side dressing at } 35 \mathrm{DAS})\end{array}$ & 55.8 & 32 & 2484.30 & 172058 & 4.16 \\
\hline $\begin{array}{l}9.60 \mathrm{~kg} \mathrm{P} / \mathrm{ha}+400 \mathrm{~kg} \mathrm{G} / \mathrm{ha}(75 \% \text { basal }+ \\
25 \% \text { side dressing at } 35 \mathrm{DAS})\end{array}$ & 56.3 & 31.3 & 2264.00 & 150365 & 3.68 \\
\hline SEm $( \pm)$ & 1.96 & 1.27 & 73.7 & - & - \\
\hline $\mathrm{CD}(\mathrm{P}=\mathbf{0 . 0 5})$ & 5.87 & 3.82 & 220.96 & - & - \\
\hline
\end{tabular}

The highest net returns (172058 Rs./ha) and $\mathrm{B}: \mathrm{C}$ ratio (4.16) were obtained in groundnut fertilized with $60 \mathrm{~kg} \mathrm{P} / \mathrm{ha}+300 \mathrm{~kg} \mathrm{G} / \mathrm{ha}(75 \%$ basal $+25 \%$ side dressing at 35 DAS) (Table 1). The increase in net returns and $\mathrm{B}: \mathrm{C}$ ratio of groundnut crop in the same unit area obtained from the application of phosphorus $60 \mathrm{~kg} / \mathrm{ha}$ along with gypsum $300 \mathrm{~kg} / \mathrm{ha}(75 \%$ basal $+25 \%$ side dressing at 35 DAS) because of optimum fertilizer doses are available for the crop and moreover, the split application of gypsum leads to availability of Sulphur and calcium to crop during grand growth phase leads to better growth and development of pods.

In conclusion the light of above study application of phosphorus $60 \mathrm{~kg} / \mathrm{ha}$ along with gypsum $300 \mathrm{~kg} / \mathrm{ha}(75 \%$ basal $+25 \%$ side dressing at 35 DAS) recorded maximum yield and economic returns.

\section{Acknowledgement}

I express gratitude to my advisor Prof. (Dr.) Joy Dawson for constant support and guidance. I am indebted to Prof. (Dr.) Thomas Abraham, Dr. Vikram Singh, Dr. Rajesh Singh and all the faculty members of SHUATS for inspiration.

\section{References}

Amruth, B., Thippeshappa, G.N. and Chandra Sekhar, B. 2017. Effect of phosphorus levels through Integrated Nutrient Management (INM) packages on different parameters of groundnut crop. Bulletin of Environment, Pharmacology and Life Sciences, 6(1): 107- 12.

Bandopadhyay, P. and Samui, R.C. 1999. Response of kharif groundnut to 
varying levels of phosphorus, potassium and Sulphur in West Bengal. Journal of Oilseeds Research, 16: 82-85.

Choudary, J.H., Ramdev, Sutaliya and Desai, L.J. 2015. Growth, yield, yield attributes and economics of summer groundnut (Arachis hypogaea L.) as influenced by integrated nutrient management. Journal of Applied and Natural Science, 7(1):369 - 372.

Hasan, M., Ismail, B.S. 2016. Effect of phosphorus fertilizer on growth and yield of groundnut, AIP Conference Proceedings, doi. Org/10.1063/1.4966856.

Mirvat, E.G., Magda, H.M., and Tawfik, M.M. 2006. Effect of phosphorus fertilizer and foliar spraying with zinc on growth, yield and quality of groundnut under reclaimed sandy soils. Journal of Applied Science and Research, 2(8): 491-496.
Rao, S.S. and Shakawat, M.S. 2001. Effect of organic manure, phosphorus and gypsum on growth, yield and quality of groundnut (Arachis hypogaea L.). Indian Journal of Plant physiology, 6(3): 306-311.

Satish, I. and Shrivastava, S.K. 2011. Nutritional study of new variety of groundnut (Arachis hypogaea L.). African Journal of Food Science, 5(8): 490-498.

Sharma, B.M. and Yadav, J.S.P. 1997. Availability of phosphorus to grain as influenced by phosphatic fertilization and irrigation regimes, Indian Journal of Agriculture Science, 46: 205-210.

Sreelatha, N. Seshaiah, B.V. and Sankara Rao, V. 2004. Effect of phosphorus and sulphur nutrition on nutrient composition oil content and yield of groundnut. The Andhra Agricultural Journal, 15(3\&4): 380-383.

\section{How to cite this article:}

Vidya Sagar, D. R. M. S., Joy Dawson and Ramasahayam Uday Kumar Reddy. 2020. Effect of Phosphorus and Gypsum on Growth, Yield and Economics of Groundnut (Arachis hypogea L.). Int.J.Curr.Microbiol.App.Sci. 9(10): 1635-1638. doi: https://doi.org/10.20546/ijcmas.2020.910.196 